\title{
Theme Expression of Indian Film Hichki
}

\author{
Yanjuan Qi \\ College of Marxism, Heilongjiang Bayi Agriculture University, Daqing, China \\ Email:25354716@qq.com
}

How to cite this paper: Qi, Y. J. (2020). Theme Expression of Indian Film Hichki. Art and Design Review, 8, 1-5. https://doi.org/10.4236/adr.2020.81001

Received: November 11, 2019 Accepted: December 16, 2019 Published: December 19, 2019

Copyright $\odot 2020$ by author(s) and Scientific Research Publishing Inc. This work is licensed under the Creative Commons Attribution International License (CC BY 4.0).

http://creativecommons.org/licenses/by/4.0/

\begin{abstract}
In the autumn of Indian film Hichki in 2018, it appeared in the $21^{\text {st }}$ session of the Shanghai international film festival in order to "zero bad review" and was known as "2018 best campus movie", and became the accompanying with "starting line" to reflect the education reality. Through the analysis of the narrative of film skill, this paper discussed the film composite theme of acceptance, express love and respect by combining with the film aesthetics, psychology, and pedagogy.
\end{abstract}

\section{Keywords}

Hichki, Narrative Skill, Theme

\section{Introduction}

Hichki (Figure 1) tells a story that Naina, who suffers from Tourette's syndrome, leading a group of poor students to make a successful comeback on campus. Tourette Syndrome will cause involuntary muscle twitching and blinking and the sufferer will make a weird noise like a boing sound. Naina was ridiculed at school for being a Tourette Syndrome, and after being rejected several times as a teacher. She was finally accepted by her Alma Mater and made the head of Class $9 \mathrm{~F}$, the worst class of all. After many practical jokes, students finally understood the sincere and love of teacher Naina. Naina's real acceptance and respect toward students awaken the hearts of students. Talking about Parabola by throwing eggs on the playground, talking about heat energy while playing basketball, laughing in the laboratory, these interesting ways of taking class attracted tired but clever children. Naina became the star of the students. Analyzing the film carefully, moving aside, it is worth to analyze in depth toward the director's narrative skill and the theme. 


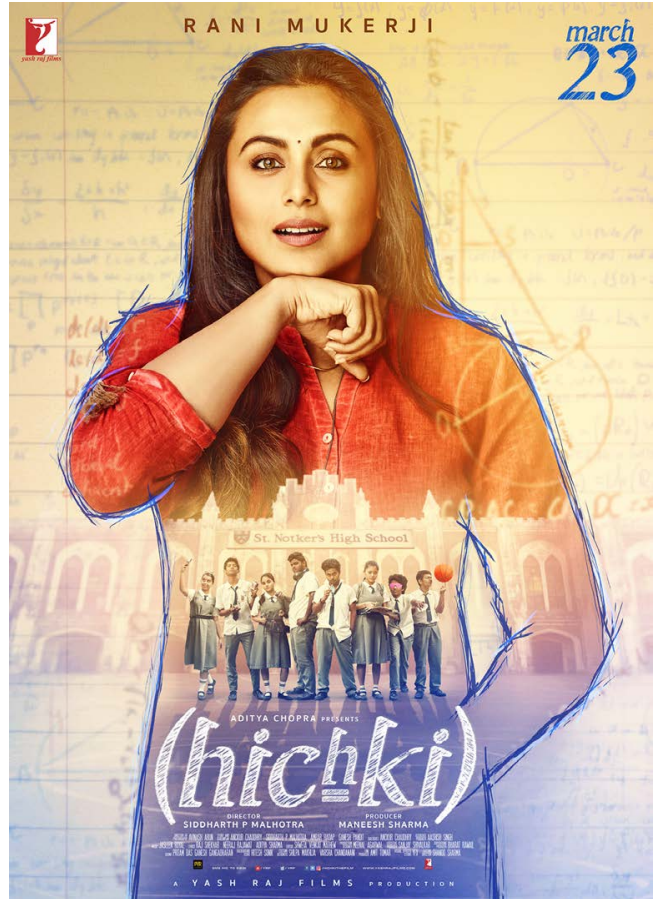

Source: https://www.imdb.com/title/tt6588966/mediaviewer/rm3946467584.

Figure 1. Poster of Hichki.

\section{The Use of Narrative}

The core spirit of realism movie is to reveal the nature of life, and the skill can be divided into reality, realism and expressionist (tradition) to form a documentary division of realistic aesthetics, aesthetics and expressive aesthetics, but as India realism film, it can be said to be all above three points (Mou \& Yang, 2012). Hichki points to the social reality with real people and things as the prototype.

\subsection{The Use of Contrast Methods}

One contrast is the teacher of Naina and Wadia. Film Hichki revolved around their attitude to the $9 \mathrm{~F}$ class including of students to fry bad classroom glass, students of two class to fight in the library, the prefect badge of Naina's teaching methods, the students' disposition of breaking entries and cheating in the exam question $9 \mathrm{~F}$ class, and all aspects show the different position and shape of the different types of teachers teaching and educational concept.

Second contrast is the attitude of film father and Wadia before and after. Especially Wadia knows that his protege leaks wrong examination question to have cough and ponder, then he has the attitude change toward the $9 \mathrm{~F}$ class. So some scholar articles review the counter of $9 \mathrm{~F}$ class to depend on the transition of $9 \mathrm{~A}$ class teacher, and the processing logic is chicken soup. And the author thinks this reflects the opposite characters remain professional ethics and conscience of 9 A class teacher. It is too ideal by processing skill and transferring the humanity awakening, which accords with self-help theme of film.

Third contrast is the reality of the class antagonisms, the gap between rich and 
poor. Naina visits to the parents of schoolchildren from door to door and shows typical microcosm difference society in India. Ink is not much, but the film art reveal the pain points of the society.

\subsection{The Application of Colour}

Using color change to reflect psychological characters and foil atmosphere, when principal Khan pleased Naina to walk onto the stage, at the moment the picture was divided into two kinds of color, the light of the stage was warm color and the audience is dark cool color. As little Naina slowly walked onto the stage, the moment of lens reflects Naina's spirit from dark to light, Naina walked slowly, and it depicted the little Naina's all the uncertainty and insecurity. The color changes of Naina's clothes reflected the psychological characters in the film, Naina was employed by Alma mater, she dressed in green clothes to visit the headmaster, and the green represented the hope and a new start in life. In the next two days, she wore a jacket with the white flowers and pink peach, it meant that the Naina was a teacher with joy. When students make mischief and damage school entries, her clothes color was dark blue color clothes to correspond with the low mood. Artie found restaurant to apologize to Naina, and she dressed in white clothes to imply the value of empathy between teachers and students.

\subsection{The Use of Music, Singing and Dancing}

As a national culture characteristic, the new century of Indian films strengthen the narrative penetration of music and songs, strengthened the background music songs and melodies of positive role in the film, and improved the quality of the production, technical quality and intensity of expression and appeal. The film had two pieces of song and dance of "hip-hop music" from students to make a fun teacher. They sang in the hallway, "they are Wi-Fi, we are 3 G.", When the song sounded over and over again, they were helpless at moment, and had the bizarre and pure smile on children face of in the $9 \mathrm{~F}$ class. The lyrics songs of studying hard in the $9 \mathrm{~F}$ class reflected the speculative knowledge of the children for hiccups, and the music of the teaching methods showed students happy to learn. In the end, the film inserted more authentic Indian dance.

\section{The Complex Expression of Theme}

\subsection{The Acceptance}

In the field of psychological research, self-acceptance concept refers to the individual completely and unconditional acceptance of the self characteristic, feelings, life experience and all related content. The self acceptance attitude includes the accepting yourself body, ability and character of positive value and exists some shortcomings and errors (Chen, 2009).

Films conveyed the first theme was accepted. First, the expression was Naina's the self acceptance, and the film has two direct points, Naina said that she and Tourette syndrome are as the "we", and so Naina had to face and actively accept 
the disease as a part of yourself. She told her father that she didn't need to solve Tourette syndrome at the end of film, and said that "this is me, I will always like this". Second, the film conveyed that all people should be acceptance of self and others. The school accepted $9 \mathrm{~A}$ to $9 \mathrm{~F}$ classes, the mind fear of $9 \mathrm{~F}$ class students and Wadia's changes of self self-teaching ideas at small aspect, and the education accepted equality, social accepted the weak and the country accepted the unfair at big aspect.

\subsection{The Respect}

Naina suffered from Tourette syndrome, it made her be laughed, rejected and abandoned in the study and work, but she decided to challenge the fate of injustice on the counter attack path and wanted to be a teacher, and she showed that the ordinary people couldn't reach success, and this was a movie hero of self respect. Naina brought the poor grades of no one dare to teach students, she firmly believed that "there are no poor students, only bad teachers". She adopted the interesting teaching to create that the "poor students" could make wonders, and it all came from teacher to student's respect. The school would arrange slums of students in one class, which reflected the various inequality of society. This was a movie of giving everyone to proper respect.

\subsection{The Love}

Bajin said: "I have love and hate, sorrow and longing in the life. When I was writing, I have myself love and hate, sorrow and longing. If it hadn't above all, and I wouldn't write the novels" (Ba, 1962). Love is the eternal theme in the world, and love is the only thing that we can't live up. Love of the display and interpretation of film is bringing to the impressed and touched the core theme of soul for audience.

Film narrative flowed love. First, Naina gets love. Naina was laughed at by her classmates and forced to transfer to another school, her father called his daughter's hiccups a dog, which made her sad. However, at the same time, Naina is lucky to have a mother, a younger brother and the understanding, acceptance and love of Khan. This love becomes the power that Naina turns inferiority complex into strength and progress. Second, Naina delivers love. The reason that Naina persists the choice of teacher position is the encouragement and love of principal Khan, which changed Naina's life. Naina always has such a desire to pass on this love and mission to give more students life inspiration.

Film focuses on Naina's sincere, pure love to the student, which made the audience to feel the real characters. The hiccup teacher understood the deep respect for individual dignity, and this seemed to be connected with the audience in terms of the emotional atmosphere and spiritual world. Film analyzed the character of 9A Wadia, and he loved his students from efforts to cultivate good grades students and pay for the personality deviation students, which showed his expectations of students and love. Although his love was different with Naina in 
ways, but the final destination was to cultivate students to become the comprehensive talent. That last sentence "you (Naina) are right all the time, there are no bad students, and there are only bad teachers", and the theme of love was sublimated again.

\section{Conclusion}

Hichki based on education, tells the sensitive issue of teacher-student relationship. It uses contrast technique, color, music, dance and other elements with Indian national characteristics, conveys the theme of acceptance, love and respect between teachers and students. Being full of positive energy to the heart of everyone, which also reflects the human care, arouses the audience's resonance. It is a very valuable and shocking film.

\section{Funding}

The work is supported by humanities and social science research project of ministry of education in 2018 (18JD710031).

\section{Conflicts of Interest}

The author declares no conflicts of interest regarding the publication of this paper.

\section{References}

Ba, J. (1962). Family (445 p). Beijing: People Literature Press.

Chen, H. Y. (2009). Analysis of Self-Acceptance from the Perspective of Evolutionary Psychology. Journal of Mudanjiang Education College, 6, 99-113.

Mou, Y. Y., \& Yang, J. X. (2012). Realism Style Study of Indian Movie Realism in Nearly Years. Movie Literature, 4, 15-16. 